\title{
Primary Brain Ewing Sarcoma/pPNET in Elder Adult
}

\author{
Rato J* and Lopes A \\ Department of Neurosurgery, Centro Hospitalar e Universitário de Coimbra, Portugal
}

Submission: March 01, 2017; Published: April 25, 2017

*Corresponding author: Rato J, Department of Neurosurgery, Centro Hospitalar e Universitário de Coimbra, Portugal, Email: joanacatarina79@gmail.com

\begin{abstract}
The Ewing sarcoma/peripheral primitive neuroectodermal tumour type tumour (EWS/pPNET) group includes those small round blue cell tumours with morphological attributes of the germinal neuroepithelium. It represents a group of rare primary intracranial tumours, mostly described in paediatric population. There are very rare reports of primary intracranial EWS / pPNET in elders. We report the case of an 83-yearold man, where a cerebellar-pontine lesion mimicking a meningioma turned out to be a EWS/pPNET. Genetic studies were not performed, as he was not to be submitted to chemotherapy.
\end{abstract}

Keywords: EWS/pPNET; Ewing sarcoma; Peripheral primitive neuroectodermal tumour; Cerebellar-pontine angle

\section{Introduction}

Ewing sarcoma / peripheral primitive neuroectodermal tumour type tumour (EWS / pPNET) are very rare tumours (1\% of all sarcomas); Ewing's sarcoma represents 5 to $15 \%$ of malignant bone and soft tissue tumours; two thirds of cases of Ewing's tumours occur before age 35 years, with a median age of 20 years [1]. Primary brain tumour cases in adults are found in reports literature [2,3]. Ewing sarcoma / peripheral primitive neuro ectodermal tumour type tumour (EWS / pPNET), belongs to a tumour family that shares clinicopathologic and molecular genetics features. Histologically, its family is recognized as a small, round, blue cell tumour, staining positively for CD99 and usual genetic features gene rearrangements between chromosome 22 and 11 (22q11 EWSR1/FLI1) or FUS (chromosome 16) [4]. Primary brain tumours of this sort are rare (a review of the literature revealed 19 cases), being the eldest a 67-year old female [5-22]. They are classified per the 2016 WHO Classification as mesenchymal, non-meningothelial tumours [4].

\section{Review of the Case}

We report the case of an 83-year-old man, autonomous, who presented at the emergency department with complaints of numbness on the right side of the face lasting 3 months. The patient underwent a head-CT, which demonstrated the presence of an extra-axial lesion on the right cerebellar-pontine angle, approximately $2 \mathrm{~cm}$ wide, and was referred for a neurosurgical appointment. He returned a month later to the emergency department complaining of a severe loss of balance that deemed him unable to walk. He repeated the head-scan which showed that the lesion had doubled in size within this timespan. A headMRI was performed and the lesion resembled a meningioma. The patient underwent surgery 2 weeks later and total removal of the lesion was achieved via retrosigmoid craniotomy. In the immediate postoperative period, he presented a right peripheral facial palsy, House-Brackman 4, and therefore a tarsorrhaphy was performed. He recovered partially of his facial palsy, and is now able to walk. No further lesions were found and he is scheduled to start radiotherapy [23].

\section{Discussion}

The histology of the lesion revealed a small, round cell tumour with an immunophenotype favouring the Ewing sarcoma / peripheral primitive neuroectodermal tumour type tumour (EWS / pPNET). Genetic studies were not performed in this case, since the patient was not to be submitted to chemotherapy. These are very rare tumours, mostly appearing on paediatric age and therefore the diagnosis and prognosis factors are unknown. Ibrahim et al. [24] in their recent review, proposed some possible prognostic factors, some of which are applicable to Ewing sarcoma in a broader sense. Specifically, age greater than 17 years, inaccessibility of the tumour for surgical resection, incomplete resection, multifocality, and tumour genetic factors (e.g. Type 1 fusion gene) appear to have negative prognostic implications. There is not enough data on the matter to draw a 
conclusion other than it is a diagnostical challenge to distinguish these tumours from other with similar characteristics; but it is fundamental to do so, ensuring that proper follow-up and complementary treatments are administered.

\section{References}

1. http://atlasgeneticsoncology.org/Tumors/EwingID5010.html.

2. Khan SA, Ujjan BU, Salim A, Shamim S (2016) Cerebellopontine angle primitive neuroectodermal tumor mimicking trigeminal schwannoma, Surg Neurol Int.

3. Kalamarides M, Dewolf E, Couvelard A, Shahidi A, Bouccara D, et al. (2001) Extraaxial primitive neuroectodermal tumor mimicking a vestibular schwannoma: Diagnostic and therapeutic difficulties. Report of two cases. J Neurosurg 94(4): 612-616.

4. Vanden Heuvel KA, Al-Rohil RN, Stevenson ME, Qian J, Gross NL, et al. (2015) Primary intracranial Ewing's sarcoma with unusual features, Int J Clin Exp Pathol 8(1): 260-274.

5. Louis DN, Perry A, Reifenberger G, Von Deimling A, Figarella-Branger D, et al. (2016) The 2016 World Health Organization Classification of Tumors of the Central Nervous System: a summary. Acta Neuropathol 131(6): 803-820.

6. Pekala JS, Gururangan S, Provenzale JM, Mukundan S (2006) Central nervous system extraosseous Ewing sarcoma: radiologic manifestations of this newly defined pathologic entity. AJNR Am J Neuroradiol27(3): 580-583.

7. Kazmi SA, Perry A, Pressey JG, Wellons JC, Hammers Y, et al. (2007) Primary Ewing sarcoma of the brain: a case report and literature review. Diagn Mol Pathol 16: 108-111.

8. Mazur MA, Gururangan S, Bridge JA, Cummings TJ, Mukundan S, et al. (2005) Intracranial Ewing sarcoma. Pediatr Blood Cancer 45: 850-856.

9. Jay V, Zielenska M, Lorenzana A, Drake J (1996) An unusual cerebellar primitive neuroectodermal tumor with $\mathrm{t}(11 ; 22)$ translocation: pathological and molecular analysis. PediatrPathol Lab Med 16: 119128.

10. Papotti M, Abbona G, Pagani A, Monga G, Bussolati G (1998) Primitive Neuroectodermal Tumor of the Meninges: An Histological, Immunohistochemical, Ultrastructural, and Cytogenetic Study. Endocr Pathol 9(3): 275-280.

11. Antunes NL, Lellouch-Tubiana A, Kalifa C, Delattre O, Pierre-Kahn A, et al. (2001) Intracranial Ewing sarcoma/'peripheral' primitive neuroectodermal tumor of dural origin with molecular genetic confirmation. J Neurooncol 51(1): 51-56.
12. Dedeurwaerdere F, Giannini C, Sciot R, Rubin BP, Perilongo G, et al. (2002) Primary peripheral PNET/Ewing's sarcoma of the dura: a clinicopathologic entity distinct from central PNET. Mod Pathol 15(6): 673-678.

13. D'Antonio A, Caleo A, Garcia JF, Marsilia GM, De Dominicis G, et al. (2004) Primary peripheral PNET/Ewing's sarcoma of the dura with FISH analysis. Histopathology 45(6): 651-654.

14. Mobley BC, Roulston D, Shah GV, Bijwaard KE, McKeever PE (2006) Peripheral primitive neuroectodermal tumor/Ewing's sarcoma of the craniospinal vault: case reports and review. Hum Pathol. 37(7): 845853.

15. Attabib NA, West M, Rhodes RH (2006) Peripheral primitive neuroectodermal tumor of the cavernous sinus: case report. Neurosurgery 58(5): E992.

16. Navarro R, Laguna A, de Torres C, Cigudosa JC, Sunol M, et al. (2007) Primary Ewing sarcoma of the tentorium presenting with intracranial hemorrhage in a child. J Neurosurg 107: 411-415.

17. Mellai M, Caldera V, Comino A, Fortunato M, Bernucci C, et al. (2010) PNET/ESFT of the cranial vault: a case report. ClinNeuropathol 29(6): 372-377.

18. Choudhury KB, Sharma S, Kothari R, Majumder A (2011) Primary extraosseous intracranial Ewing's sarcoma: Case report and literature review. Indian J Med Paediatr Oncol 32(2): 118-121.

19. Bunyaratavej K, Khaoroptham S, Phonprasert C, Tanboon J, Shuangshoti S (2005) Primary intracranial peripheral primitive neuroectodermal tumor/Ewing's sarcoma presenting with acute intracerebral hemorrhage. ClinNeuropathol 24(4): 184-190.

20. Stechschulte SU, Kepes JJ, Holladay FP, McKittrick RJ (1994) Primary meningeal extraosseous Ewing's sarcoma: case report. Neurosurgery 35(1): 143-147.

21. Katayama Y, Kimura S, Watanabe T, Yoshino A, Koshinaga M (1999) Peripheral-type primitive neuroectodermal tumor arising in the tentorium. Case report. J Neurosurg 90(1): 141-144.

22. Niwa J, Shimoyama N, Takahashi Y (2001) Primitive neuroectodermal tumor involving the frontal skull base in an infant. Childs Nerv Syst 17(9): 570-574.

23. Simmons MA, Luff DA, Banerjee SS, Ramsden RT (2001) Peripheral primitive neuroectodermal tumour (pPNET) of the cerebellopontine angle presenting in adult life. J Laryngol Otol. 115: 848-852.

24. George M Ibrahim, Aria Fallah, Mehdi Shahideh, Uri Tabori, James T Rutka (2012) Primary Ewing's sarcoma affecting the central nervous system: a review and proposed prognostic considerations. Journal of Clinical Neuroscience 19(2): 203-209

\section{Your next submission with Juniper Publishers will reach you the below assets}

- Quality Editorial service

- Swift Peer Review

- Reprints availability

- E-prints Service

- Manuscript Podcast for convenient understanding

- Global attainment for your research

- Manuscript accessibility in different formats

( Pdf, E-pub, Full Text, Audio)

- Unceasing customer service

Track the below URL for one-step submission https://juniperpublishers.com/online-submission.php 